
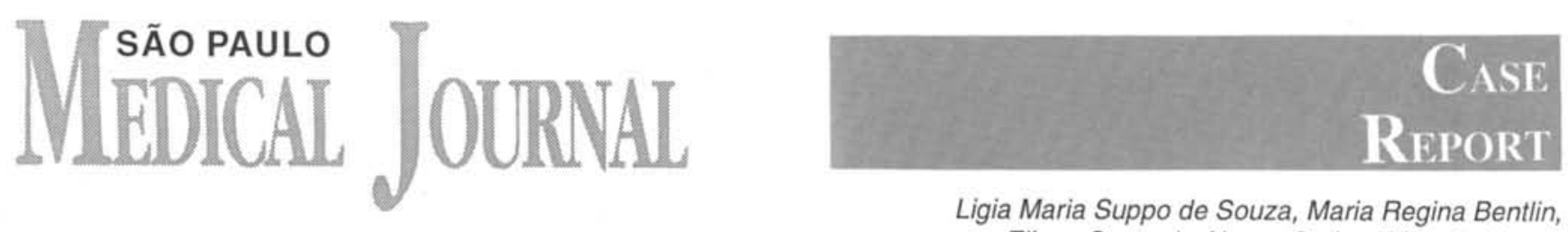

Ligia Maria Suppo de Souza, Maria Regina Bentlin, Eliana Souto de Abreu, Carlos Eduardo Bacchi

\title{
Systemic congenital lymphangiomatosis
}

Neonatal Unit, Departments of Pediatrics and Pathology, University Hospital, Botucatu School of Medicine, UNESP, Botucatu - São Paulo, Brazil

\begin{abstract}
Systemic lymphangiomatosis is a rare disease characterized by the exageration of lymphatic channel proliferation, occurring in children and young adults. We describe an extremely rare case of congenital systemic lymphangiomatosis in a newborn who had ascitis and respiratory failure develop immediately after delivery. Death occurred during the first hour of life. Autopsy findings showed numerous cysts in soft tissues of the cervical area, mediastinum and diaphragm, and several other organs including the liver, spleen, thyroid and kidneys. The severe and diffuse involvement with cysts in both lungs by lymphangiomatosis was associated with poor prognosis and death in our case.
\end{abstract}

UNITERMS: Lymphangiomatosis. Lymphangioma. Congenital lymphangiomatosis.

\section{INTRODUCTION}

Lymphangiomatosis is a rare disorder characterized by proliferating lymphatic channels in osseous or extraosseous tissues, in a diffuse fashion. This type of cystic angiomatosis represents a generalized lymphatic abnormality, and many of the cases occur in children and young adults. ${ }^{1,2}$ The prognosis is dependent upon the extent of dissemination, being very poor when vital organs are affected. ${ }^{2.3 .4}$ We report, as far as we are aware, the first case of systemic congenital lymphangiomatosis described in the literature. Autopsy findings, immunohistochemical study and review of literature are also presented.

\author{
Adress for correspondence: \\ Carlos Eduardo Bacchi \\ Faculdade de Medicina - UNESP - Depto. de Patologia \\ Botucatu/SP - Brasil - CEP 18618-000
}

\section{CASE REPORT}

A $3.2 \mathrm{~kg}$ female infant was delivered at 34 weeks gestation by Caesarean section, with a predelivery diagnosis of fetal ascitis. When she was born. Apgar was 2-1-1, and the physical examination revealed large ascitis, an abdominal tumor mass, cervical gibbosity and frontal hypertrichosis.

Paracenthesis was performed with the withdrawa of $500 \mathrm{ml}$ of serosanguineous fluid. She developed cardiorespiratory arrest, and death occurred within the first hour of life. Post-mortem $\mathrm{x}$-ray evaluation revealed normal bone formation.

Autopsy Findings: Figures 1 to 3 demonstrate the macroscopic and microscopic findings. During autopsy, the thoracic organs were compressed by the $1,000 \mathrm{ml}$ ascitis. The visceral surface of the lungs revealed multiple subpleural cysts. The pulmonary cut surface showed cystic cavities of several sizes measuring up $0.8 \mathrm{~cm}$, which were frequently multiloculated and usually contained clear 


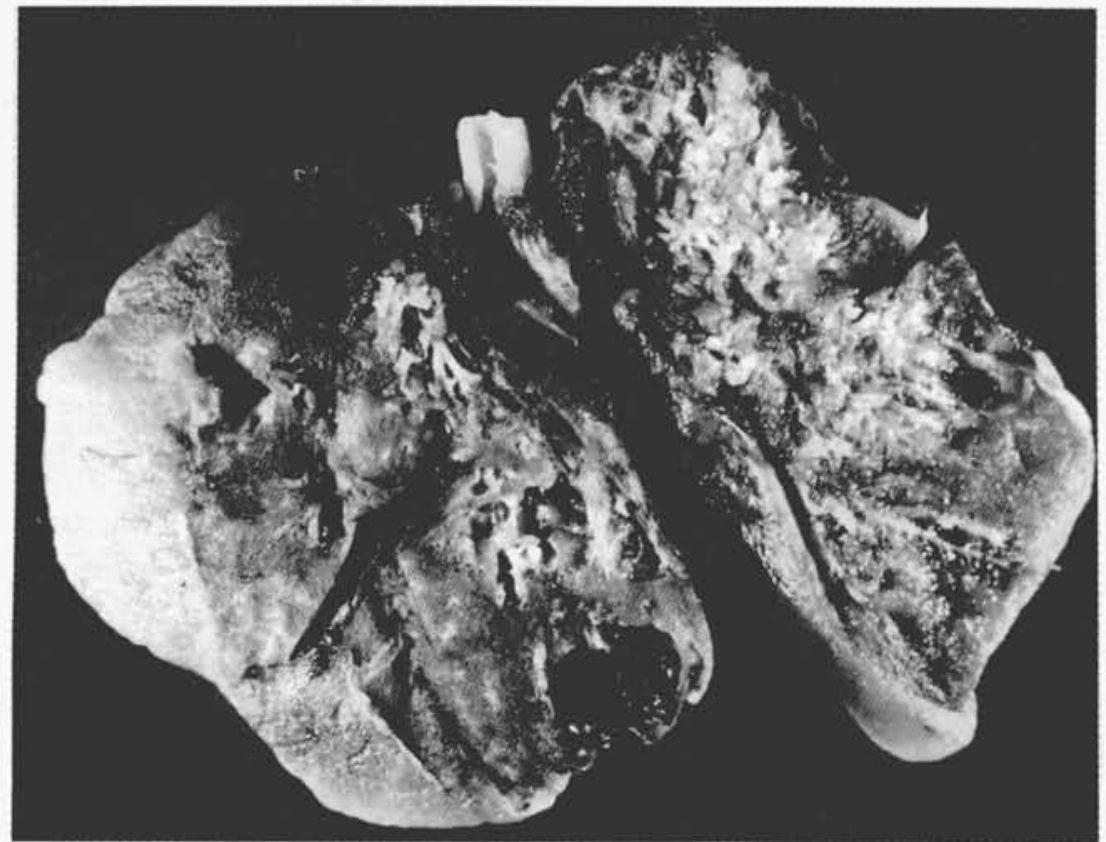

Figure 1 - Pulmonary cut surface showing cystic cavities of several sizes in both lungs.

proteinaceous fluid (Fig. 1). The same type of cysts were visualized in soft tissues of cervical area; mediastinum and diaphragm (Fig. 2); and also in several organs, namely the spleen, liver, thyroid and both kidneys. Bone abnormality was not present. Multiple cysts, including a large $3.0 \mathrm{~cm}$ one, were present between the gastric serosa and splenic hilus. These cysts compressed the portal vascular system, causing portal hypertension with thrombosis of the portal vein and ascitis. Microscopically, all the cysts were formed by proliferation of anastomosing, thin-walled lymphatic channels (Fig. 3). These vessels were lined by flattened endothelial cells that stained positively with an immunohistochemical stain for factor VIII related antigen.

\section{DISCUSSION}

Lymphangiomatosis is a rare condition occurring equally in both sexes and characterized by multifocal proliferation of lymphatic vessels that are lined by cytologically benign endothelia. ${ }^{1}$ This disease does not appear to be hereditary, ${ }^{5}$ and has been diagnosed at almost any age, including the pediatric group.

Several authors have considered lymphangiomatosis as a benign vascular tumor or part of a systemic cystic angiomatosis syndrome. ${ }^{1.3}$

Lymphangiomatosis can be classified into three categories: 1. Simple: composed of capillary-sized, thin-walled lymphatic channels; 2 . Cavernous: made with fibrous adventitial coats; 3 . Cystic. The case reported here can be classified as systemic mixed type of simple and cysts. Among the localized forms of lymphangiomatosis, the osseous type is the most common and usually has good prognosis with the diagnosis being made late in life. ${ }^{1.5}$ As in our case, the systemic form usually involves lungs, pleura, soft tissues, liver spleen, kidneys and large intestines. ${ }^{2.6}$

The clinical presentation of lymphangiomatosis depends on the anatomic site and the extension of involvement. It can manifest with anorexia, localized pains, hepatosplenomegaly, ascitis, and several degrees of respiratory distress and multiple osseous fractures. ${ }^{3}$ The final clinical diagnosis is usually difficult due the rarity of this disease and diversity of signs and symptoms.

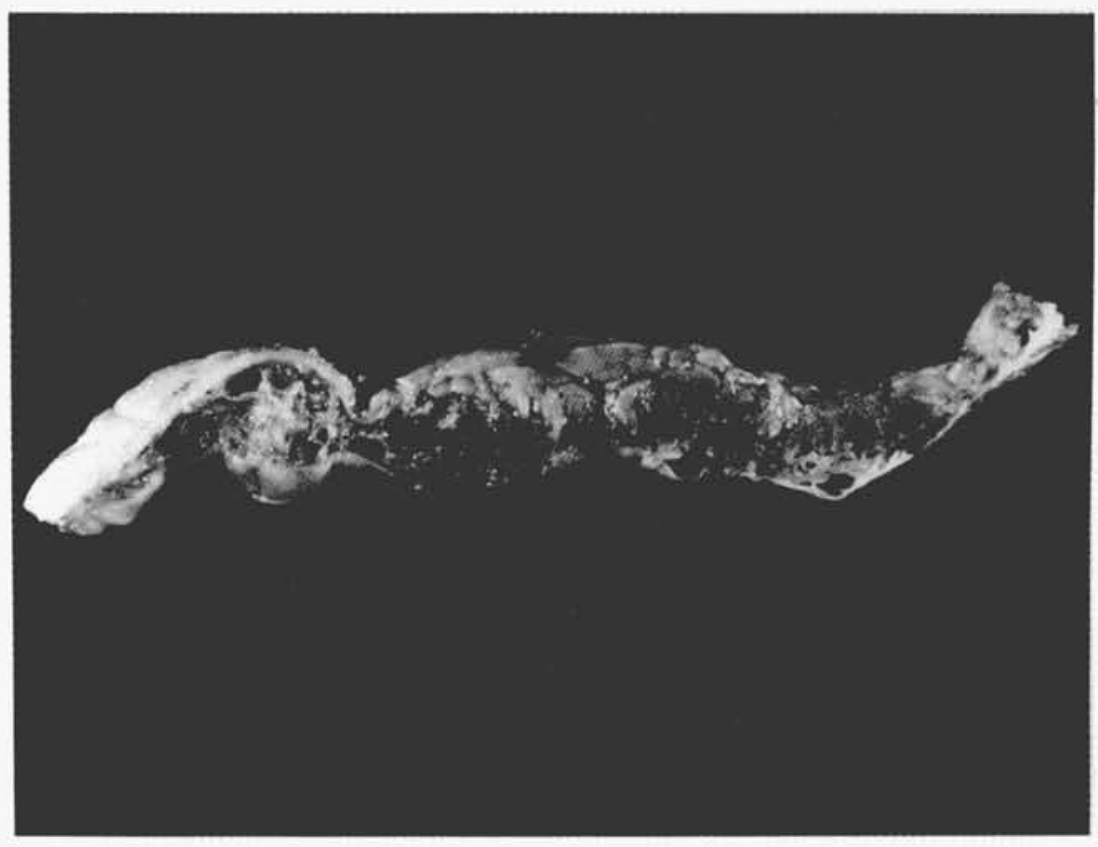

Figure 2 - Longitudinal cut of diaphragm revealing multiple cysts present in abdominal surface. 


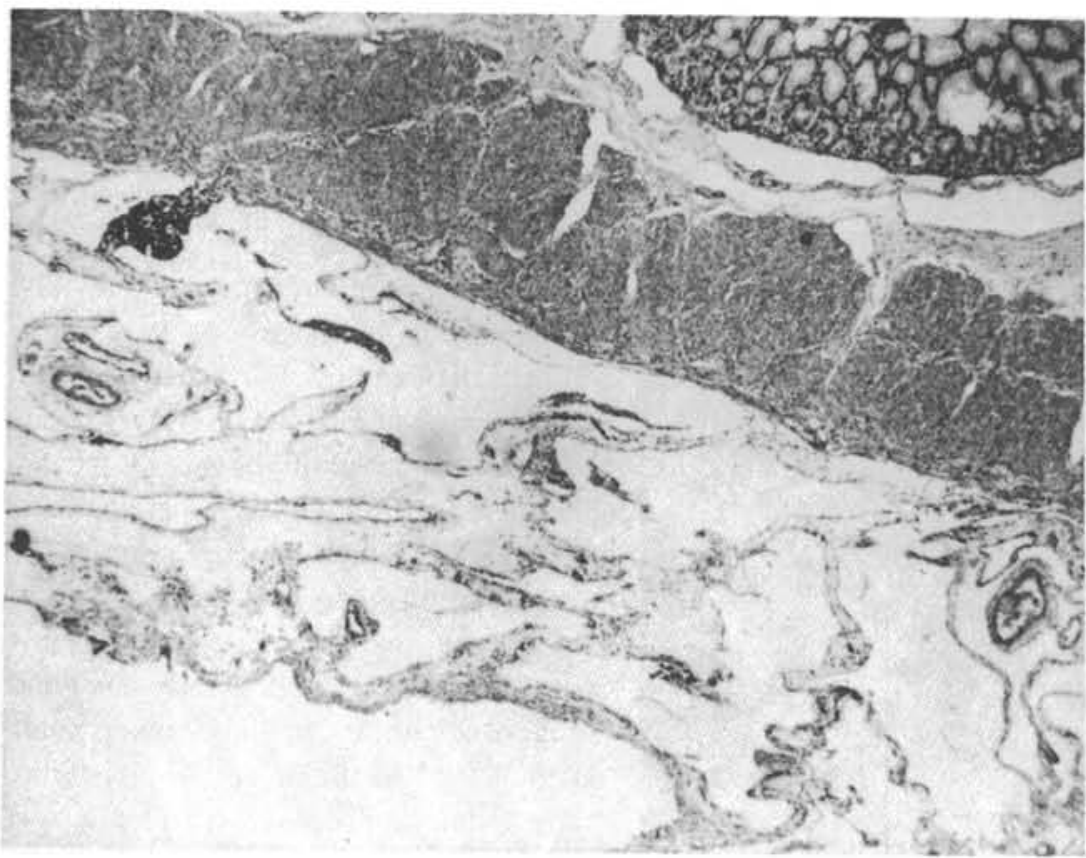

Figure 3 - Presence of cysts formed by proliferation of anastomosing, thin-walled lymphatic channels in subserosa area of gastric wall (HE x 200).

Radiological examination may be helpful in the diagnosis, depending on the anatomical location of the lesions. It may reveal mediastinum enlargement, lytic lesions and fractures. ${ }^{2}$ Ultrasound study is of value to visualize visceral involvement and possible compression of vascular structures.' There are no laboratory tests patognomonic of lymphangiomatosis, and biopsy is the only procedure to be used for the diagnostic conclusion.

The choice of treatment for lymphangiomatosis depends on the severity and type of involvement; namely, treatment of fractures and surgical procedure to remove cysts compressing vital structures. ${ }^{2.7}$

The severity of lymphangiomatosis is related to the anatomical site and extent of involvement. It has a favorable prognosis when it is localized, and a poor prognosis when vital organs, including vertebral medulla, are involved. ${ }^{3}$ When the disease is diffuse and extensive in a particular organ, as in the lungs in our case, the prognosis is also very poor.

The principal differential diagnoses of lymphangiomatosis are: lymphangiomyomatosis, which is described more often for women in reproductive life; pulmonary interstitial emphysema, especially in newborns who have undergone mechanic ventilation; Gorham's disease, which is characterized by regional or focal involvement of the bones; pulmonary capillary lymphangiomatosis associated with capillary proliferation of alveolar septa; and signs and symptoms of pulmonary hypertension ${ }^{3}$ and congenital pulmonary lymphangectasia due to a primary defect of the development of lymphatic vessels or secondary to cardiovascular alterations.

Our patient presented a severe systemic involvement of lymphangiomatosis at the neonatal period. This presentation seems to be extremely rare, and to our knowledge is the first case in a newborn described in the literature. The patient already had an important manifestation of her disease, still intrauterus, characterized by ascitis, which was cause by the compression of the portal system by multiple cysts presented in the splenic hilus. Also, the severe pulmonary involvement with large number of cysts in both the lung parenchyma and subpleural regions was probably responsible by respiratory failure, also aggravated by ascitis. The autopsy confirmed the diffuse and severe involvement of both lungs by lymphangiomatosis, which is associated with very poor prognosis and led to early death in our case. 


\section{RESUMO}

A linfoangiomatose é uma doença rara, caracterizada pela exarcebação da proliferação dos canais linfáticos, ocorrendo em crianças e adultos jovens. Nós descrevemos um caso extremamente raro de linfoangiomatose sistêmica congênita, em um recém-nascido que apresentava ascite e insuficiència respiratória, desenvolvidos imediatamente após o nascimento. O óbito ocorreu nas primeiras horas de vida. Achados de autópsia demonstraram numerosos cistos em tecido mole da regiāo cervical, mediastino, diafragma, e em diversos outros órgāos incluindo: figado, baço, tireóide e rins. O grave e difuso acometimento de cistos nos pulmões pela linfoangiomatose foi associado ao mau prognóstico e morte no caso relatado.

\section{REFERENCES}

1. Asch, Cohen AH, Moore TC. Hepatic and splenic lymphangiomatosis with skeletal involvement: Report of a case and review of the literature. Surgery 1974;76:334.

2. Seckler SG, Rubin H, Rabionowitzs JG. Systemic cystic angiomatosis. Am J Med 1964;37:976.

3. Morphis JG, Arcinue EL, Krause JR. Generalized lymphangioma in infancy with chylotorax. Pediatr 1970;46:566.
4. Ramani P, Shah A. Lymphangiomatosis-histologic and immunohistochemical analysis of four cases. Am J Surg Pathol 1993;17:329.

5. Edwards WH, Thompson RC, Varsa EW. Lymphangiomatosis and massive osteolysis of the cervical spine. Clin Orthop Rel Res 1983;177:222.

6. Carlson KC, Parnassus WN, Klatt EC. Thoracic lymphangiomatosis. Arch Pathol Lab Med 1987;111:475.

7. Dunkelman H, Sharief N, Berman L, et al. Generalized lymphangiomatosis with chylotorax. Arch Dis Child 1989;64:1058. 